\title{
Education level, public policy and private sector HR practices determine female job participation rate: a case of Pakistan's telecom sector
}

\author{
Muniba Sana
}

\begin{abstract}
This study uses a randomly selected sample of 100 female employees of telecommunication sector of Rawalpindi-Islamabad area and tries to analyze whether government policies and private sector human resource practices exist to promote favorable environment for female job participation. The study's results indicate that female employment-participation rate estimates at 32.28 percent, suggesting that a little less than one-third of females get employment in research area under study. The respondents' perception on government policy and private sector organizational HR practices regarding female job participation are found positive; however, females still feel the necessity of making their jobs more secured and their work worthwhile. Econometrically estimated relationship suggests that female educational levels determine the female job participation at the first place, and government policy helps determine the private sector organizational $H R$ practices and policies, which further affect and encourage the female job participation. The results suggest that, for a more effective private sector female participation, the government policies need to be further strengthened and made substantiated. For future research, this study provides a base-model which may be replicated to evaluate public and private sector roles in determining female job participation of other economic sectors of Pakistan's economy.
\end{abstract}

JEL classification: J21, J82, C31

Keywords: Female job participation, public/private sector, econometric model, Pakistan

\section{INTRODUCTION}

The labor force participation plays important role in determining socio-economic growth and development of an economy, in general, while share of females in total work force of an economy contributes special part, in particular, in both developed and developing economies. According to the U.S. Department of Labor (2012), about $60 \%$ of all women in U.S. are in labor force, compared with nearly $75 \%$ of all men. U.S. women now account for $47 \%$ of total labor force in 2008 , compared to $40 \%$ in 1975 . According to ILO (2009), increased access to labor markets for women has great potential as a contribution to economic development, but only if the work in which women are engaged, is decent and productive. ILO's (2009) report highlights that women are too often trapped in insecure employment situations with low productivity and low earnings, especially in developing countries. "In wage and salaried employment across all sectors, women face persistent earnings gaps which cannot always be justified by differences in skills, experience, or tenure....... Women are often in a disadvantaged position in comparison to men in labor markets around the world". Social customs, culture, and institutions, including the legal framework, play a large part in the participation of women and younger people in the labor market. In certain cultures, where religion plays an important role, females do not engage in paid work and hence are not part of the labor force (Encyclopedia.com, 2008).

Referring to the situation in Pakistan, ILO's (2009) report mentions that, though in 2007, more than nine million Pakistani women were employed (almost four million more than in 2000 or an increase of more than 80 per cent), the employment-to-population ratio for women remained 19.9 per cent, which is four times lower than for men (79.1 per cent), and is much lower than the ratio in South Asia as a whole (33.5 per cent). Despite a significant widening of employment opportunities, gender equality in terms of labor market access has not yet been achieved in Pakistan. In general, women have lower wages than men; this can be explained in part by the large gap in educational attainment of women and men. In 2007, just 26.8 per cent of economically active women had more than 1 year of formal education, compared to 61.5 per cent of men. Relatively more women gained access to education, but equality in education is still far from being a reality in Pakistan (ILO, 2009).

Hafeez and Ahmad (2002) specifically searched in to the factors which determine the labor force participation decision of Pakistani educated married women, and identified various socio-economic and demographic factors. Their study finds that the females' education level is strong and positive determinant of female job participation; however, monthly household income, number of workers in the household other than husband and wife and financial assets are significantly and inversely related to it. Among demographic factors, age and household structure and size affect the female labor force participation. Naqvi and Shahnaz (2003) investigated in to 
the two important aspects of Pakistani women's decisions regarding their participation in economic activities and how they make these decisions. Their results indicate women are often low paid, have low skilled jobs, and are less educated. Looking at the decision-making process related to labor force participation, researchers find that women, who are older, better educated, happen to be female head of the household, or coming from smaller better off urban families, are more empowered to take decisions on their own about whether to get a job or not. In contrast, younger, poorly educated women who are from larger families, enter the labor market not out of their own choice. Decisions whether they go out and get a job are made by other members of the households at times even without their consultation.

Ejaz (2007) analyzed the data relating to the 'Pakistan Social and Living Standards Measurement Survey of 2004-05; his results suggest that age, educational attainment and marital status have significant and positive effects on female labor force participation. When women belong to the nuclear family and have access to vehicles, they are more likely to participate in economic activities, whereas a large number of children and the availability of home appliances reduce the probability of female participation in labor force. The results imply that reducing the child care burden on females and facilitating educational attainment would lead to a higher labor force participation rate for females in Pakistan. Researcher has specially observed that $70 \%$ of female labor force is illiterate, while only $7 \%$ of the remaining $30 \%$ are graduates.

Fatima and Sultana (2009) tried to trace out the U-shape relationship between female labor force participation rate and economic development of Pakistan. Results confirm that high rate of economic development is encouraging the female participation in the labor force by increasing the work opportunities for females. The females are taking full advantage of these increased opportunities by increasing their level of education attainment.

\section{A. Problem statement}

The ILO (2009) as well as other private researchers' studies referred above have brought a number of important aspects of female job participation on surface, but almost all these studies have been found quit, particularly on the roles of the public and private sectors, in the determination of female job participation. With the understanding that government policies and private sector human resource (HR) practices can contribute prime role in determining and influencing the female job participation, this researcher intends to address this issue. More specifically, this research would pursue the following research question.

Do government policies and private sector organizations' HR practices positively affect female job participation in Pakistan?

As discussed in the preceding section, pursuing such a research question would be one of the initial steps in bridging gap in the existing literature on public and private sector role in female job participation in Pakistani context, where females constitute around half of the country's total population, and can play a very significant role in country's economic development.

\section{B. Research objectives}

The intended research is expected to help achieved, particularly the following specific research objectives.

a) To analyze whether public sector policies on female job participation exist in Pakistan, and favorably affect female participation, as well.

b) To check whether private sector organizational HR policies and practices favor female job participation.

c) To develop and test a theoretical and methodological framework, at least of an initial nature, to provide a base for carrying out larger studies, aiming at bridging the existing gap in literature, on the public and private sectors roles in female job participation.

The research question narrated above and the specific research objectives enlisted here would help shape a research study which would not only provide material to bridge gap of research on public and private sectors role and contribution in female job participation, but would also encourage further research in this area.

\section{THEORETICAL FRAMEWORK}

Figure I

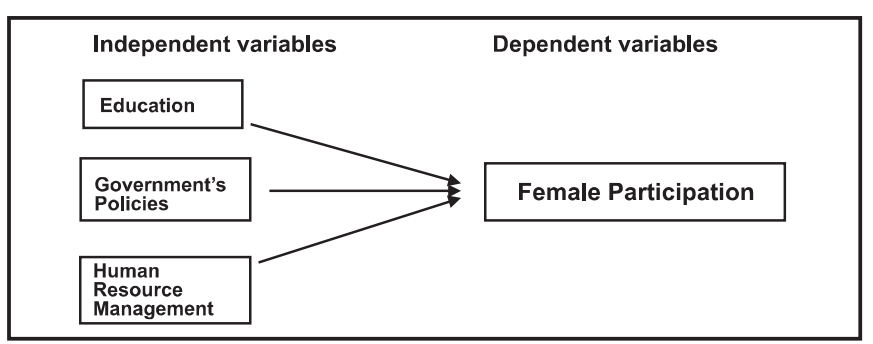

In accordance with what we have discussed earlier, the underlying rationale of this research is to determine whether the important factors like education, government policies and public and private sector HR practices and policies have been affecting female's participation in Pakistan labor force, 
and if yes, then how these and other factors have been effectively contributing, and their contributions can be made more efficient. So, we start with the basic model, wherein we check whether and how education, government policies and private sector HR practices determine female participation.

\section{METHODOLOGICAL FRAMEWORK}

The above shown relationship can best be estimated econometrically, through the model specified, as follows.

$$
F P R=\beta_{0}+\beta_{1} E D+\beta_{2} G P+B_{3} H R P+\varepsilon
$$

Here the abbreviation FPR denotes female participation rate, ED respondents' educational levels, GP government policies and HRP private sector's organizational human resource practices (HRP).

For this particular study, because of the time and other constraints, this research has been restricted to the telecom sector firms located in Rawalpindi-Islamabad area. Female participants, 100 in number, have been surveyed, using a selfadministered questionnaire, provided in appendix - I.

\section{RESEARCH FINDINGS}

\section{A. Demographics: descriptive statistics}

Information on the general demographics of the respondents of this study, covering their age, education levels and length of service experience, is provided in appendix II. The result reveals that there are 100 respondents included in the study, whose average age has been estimated at 28.67 years, with standard deviation (SD) of 3.67; the respondents' age ranged between 22 and 35 years. The respondents, on average, have 17.74 years of schooling, with SD $=1.83$ years; the respondents have education between a minimum-maximum range of 16 and 22 years. The respondent's service experience is averaged at 4.9 years, with SD $=2.05$ years; the service experience ranges between 1 and 8 years. It appears that the respondents' statistics on age and education levels are more consistent relative to variations in their experiences.

\section{B. Estimation of female job participation}

In response to three questions, stated under 'Female Participation' in questionnaire (Appendix -1 ), the respondents provided information regarding the number of their employed close-family members, relatives and neighbors, along with the total female strength; this is how data on the female job participation rate have been collected for this study. The data collected in this way have been provided in appendix III.

The average female employment-participation rate (FPR) ar- rives at 0.3228 with standard deviation of 0.1048 , suggesting that a little less than one-third of female of the sampled population is employed. These estimates of FPR are significantly higher than that shown by ILO (2009) for Pakistan (19.90\%) for year 2007. Three possible reasons can be forwarded to explain this study's higher estimates of FPR. First, there is a sizeable time-difference of the two studies; our estimates are of 2012 compared to ILO's 2007. Second, our estimates relate to Rawalpindi-Islamabad area (relatively more advanced area), while ILO (2009) talks about the average figure valid for whole of Pakistan. However, our estimates are closer to the ILO's estimates for the South Asia as a whole (33.5 per cent).

\section{Main reasons for working}

Respondents were provided four reasons for working on a job; these reasons were:
a) Empowerment
b) Independence
c) Economic needs
d) Not-to-feel-bored

Respondent were free to pick one or more reasons. Accordingly, they picked more than one reasons, ranging between a minimum-maximum range of $1-4$. However, average number of reasons remained at 1.58 , with $S D=0.6541$, suggesting that majority opted for one to two reasons (Appendix IV).

In order to explore which of the reasons-for-doing-job got more scores, the same appendix provides data on number of respondents answered 'yes'. Hence, 'economic-need' is the major reason (with the highest score of 64) for female participation in jobs, followed by empowerment (score $=44$ ) and independence (score $=37$ ); the reason feel-not-bored got the lowest response (score $=13$ ).

\section{Is the job career of your choice?}

In response to this question, 72 percent respondents said 'yes', and 28 percent were found not satisfied with their present jobs (Appendix V).

\section{E. Opportunities to find $a$ job}

Two questions (Question 5 a \& b) were meant to explore whether respondents faced difficulties in finding jobs; 65 percent respondents said 'Yes' to the first question asking 'Difficulties in finding jobs', and 73 percent said 'Yes' to the second question asking 'Finding not enough job opportunities' (Appendix VI A \& B)).

The responses on the above referred two questions are used as two items to generate a variable named as 'Difficulty in 
Finding a Job', abbreviated as DIFJ (for future reference). Taking mean value of these two items, variable DIFJ is generated; its descriptive statistic is provided in the appendix $\mathrm{VI}(\mathrm{C})$.

The newly generated variable (DIFJ) ranges between $0-1$, and averages at 0.69 , with SD $=0.3392$. The variable's mean value $=0.69$ indicates that the majority, that is, more than 50 percent respondents have said 'Yes' to the 'getting of job difficulty' question. Whether this mean value is statistically significant, using one-sample t-test; we carry out the referred test (Appendix VID \& E). Using test value $=0.5$, the one-sample t-test's results indicate that the mean difference value $=$ 0.19 is statistically significant at $t=5.602(p<0.01)$.

\section{F. Government policies}

To capture the respondents' perception regarding government policy on female job participation, two questions (Question 7 a \& b) have been included; these two questions aim at to know 'whether government is supportive' (GP1) and 'whether government has certain encouraging laws' (GP2). The descriptive statistics of the respondents' responses on these two government policy-items are provided in appendix VII. The mean values of responses on both the questions range between 2 and 5 , and average at 3.60 and 3.56, indicating that majority of respondents adopted positions in-between the 'Neutral' and 'Agreed' ones. The responses on the above referred two questions are used as two items to generate a 'government policy' variable (GP); the reliability test (Cronbach's alpha) and descriptive statistic of the newly generated variable GP are provided in appendix VII. The reliability test yields Alpha $=0.716$, which is in the acceptable range, while variable GP averages at 3.57, indicating respondents' position in-between the 'NeutralAgreed' range.

In order to further analyze whether the mean value of variable GP (= 3.57) is statistically significant, one-sample t-test has been conducted, using test value $=3$; the results are provided in appendix VII. The results of one-sample t-test regarding mean difference of government policy (GP) variable indicate that the mean difference $=0.57$ is statistically significant at $t=8.407(p>0.01)$.

Our efforts to generate a government policy variable on the basis of two questions ('whether government is supportive' and 'whether government has certain encouraging laws') have successfully resulted in yielding a variable GP, which has not only cleared a reliability test (with Cronbach's alpha score of 0.716 ) but has also stood significant on the basis of onesample t-test. As already indicated that we would not find any comparable results across literature, but with the generation of this variable and its statistical testing has helped us to achieve the first part of our research objective 1 , that requires "Analyzing whether public sector policies on female job participation exist in Pakistan........"

\section{G. Organizational HR practices}

In order to capture the respondents' perceptions whether or not the organizational HR practices (HRP) favour female job participation, 10 questions (Question $8 \mathrm{a}-\mathrm{j}$ ) were included; the descriptive statistics of the respondents' responses are presented in the appendix VIII. With the exception of two questions (Question Q4 \& Q8), the respondents' responses on all other (eight) questions have appeared on positive (Neutral-to-Agreed) side), and the mean-differences of all such responses are statistically significant at $p<0.05$ ), suggesting that the responses are more away-from 'Neutral' (= 3) than near-to 'Agreed' situation. As far as the responses to questions Q4 and Q8 are concerned, their mean values happen to be on negative (Disagreed-to-Neutral) side, and their mean-differences are statistically significant at $p<0.10$, instead of $p<0.05$. Another point which warrants attention is that the standard deviations (SD) of the responses on these two questions are relatively higher than other eight questions, suggesting that the respondents have expressed more varied views on these two questions. These two questions, respectively, ask:

$$
\begin{aligned}
& \text { Q4: “How secure do you think your Job is?" } \\
& \text { Q8: "Is your work valued in the organization?" }
\end{aligned}
$$

The above evaluation thus suggests that, whereas the majority of respondents are in agreement with the positive side of a number of organizational HR practices, they still feel the need that their jobs are made more secured, and their work be valued, as well.

To evaluate the organizational HR practices as a whole, the responses on all ten questions are aggregated in to a single variable, abbreviated as HRP, and the results of its reliability Cronbach's Alpha test, descriptive statistic and one-sample $t$ test are provided in appendix VIII.

The newly generated variable HRP averages at 3.382, with standard deviation $=0.443$ and Cronbach's Alpha reliability score $=0.694$. The one-sample $t$ test reveals that the meandifference of this variable $(=0.382)$ is statistically significant at $p<0.01$, suggesting that the respondents perceive the organizational HR practices, as a whole, positive towards the female job participation.

Similar to the earlier case of government policies (GP) variable, in this case of private sector's organizational HR practices (HRP), we have tried ten questions to generate HRP variable which has also cleared reliability test (Cronbach's alpha score $=0.694)$ as well as one-sample t-test for significance 
at $p<0.01)$. This statistical testing for significance helps us to achieve, at least partially, this research's second objective, that enquires about the existence of private sector organizational HR policies and practices. The regression analysis, being carried out in next section, would further reinforce that private sector organizational HR policies and practices favor female job participation.

\section{H. Regression Analysis: Female job participation and its antecedents}

The original model (1) required regressing female participation rate (FPR) over the respondents' educational levels (ED), government policies (GP) and organizational human resource practices (HRP); and econometrically:

$$
F P R=\beta_{0}+\beta_{1} E D+\beta_{2} G P+B_{3} H R P+\varepsilon
$$

However, the nature of the data described above, especially the data on the respondents' educational levels indicate that almost all respondents are highly educated; the frequency distribution of such data (appendix IX) further confirms that the employees belong to three distinct levels of education, suggesting that at least 16 years education is the prerequisite for having jobs in the organizations under study. Data pertains to different telecom organizations, such as Telenor, Ufone, Nokia-siemens, etc., situated in Islamabad-Rawalpindi area. The discussion in preceding section suggests that, in this particular case, female participation (FPR) first depends upon education (ED), and then on other factors, like government policy (GP) and organizational HR practices (HRP). The aforementioned econometric model (2) would thus change, as follows.

$$
\operatorname{FPR}(E D)=\beta_{0}+\beta_{1} \operatorname{HRP}(G P)+\varepsilon
$$

Whereas model (2) postulates that FPR directly depends upon ED, GP and HRP, model (3) prescribes that FPR is first determined by respondents' educational level (ED), and then by the organizational HR practices (HRP), which are in turn determined by government policies (GP).

Model 3 has now adopted the type of formulation that is referred to as Structural Equation Modeling (SEM) in management-related or Simultaneous Equations Modeling in economics-related econometrics. The model would therefore have to be estimated in two steps. In the first step, the two major components of the equation, FPR (ED) and HRP(GP) would be estimated, following the techniques:

$$
\begin{aligned}
& \operatorname{FPR}(E D)=\alpha_{0}+\alpha_{1} \mathrm{ED}+e \\
& \operatorname{HRP}(\mathrm{GP})=\nu_{0}+\gamma_{1} \mathrm{GP}+\mu
\end{aligned}
$$

In the second step, the predicted values of FPRED (estimated on the basis of equations $4 a$ ) would be regressed on predicted values HRPGP (estimated on the basis of equations $4 \mathrm{~b}$ ), using the equation:

$$
\text { FPRED }=\beta_{0}+\beta_{1} \text { HRPGP }+\varepsilon
$$

Estimating model $4(\mathrm{a}-\mathrm{c})$ yielded the results that are reported in appendix $\mathrm{X}$.

\section{Evaluation of results}

In the regression of female participation rate (FPR) over the respondents' education levels (ED), run through Model 4 (a), has not yielded very significance results in terms of R2 and Fstatistic, as well as, in terms of t-ratio and p-value; however, ED has found moderately ( $p=0.119$ ) positively determining FPR, and we have to accept these results as part of the whole/bigger model (4).

Model 4 (b), which regressed organizational HR practices and polices (HRP) over government policies (GP), has provided relatively reasonable results in terms of almost all needed diagnostic statistics, and most importantly, the explanatory variable, government policies (GP) has found statistically significantly determining $(p<0.01$ ) organizational HR practices and policies (HRP).

Model 4 (c), wherein the predicted values of FPR (found in Model 4 (a) have been regressed over predicted values of HRP (found in Model 4b) as the final part of model 4, has provided good results. $F=9.057$ indicates that model as a whole is statistically significant at $p<0.01$. T statistic $=3.010$ shows that explanatory variable, predicted values of organizational HR practices (HRP), statistically significantly determines dependent variable, predicted values of female participation rate (FPR), at $p<0.1$.

DW statistics of this model $4 \mathrm{c}$ is equal to 1.844 ; this statistic indicates two facts: first, whether or not the estimated model is suffering from autocorrelation problem specifically in case of time series data, and second, whether or not the model is misspecified. Since we have used cross-sectional data, we should not worry about autocorrelation; however, model is not even suffering from spatial-autocorrelation problem as its computed DW = 1.844 falls in no-autocorrelation zone, measuring between $d u=1.622$ and $4-d u=2.378\left(n=99, k^{\prime}\right.$ $=1 \& p=0.01$ ).

$\mathrm{DW}=1.844$ also indicate that the estimated model $4 \mathrm{c}$ is not underestimated or misspecified; for misspecification, DW should lie near to zero where DW can possibly range between $0-4$.

In addition, we also carry out a relatively more sophisticated 
model diagnostic test, generally referred to as Lagrange Multiplier (LM) test (Engle, 1982; Gujarati, 2007, pp. 534-535).

Since we have to test our following estimated model (4c) for under-fitting or misspecified.

$$
\text { FPRED }=\beta_{0}+\beta_{1} \text { HRPGP }+\mu
$$

The LM rest requires that we estimate the model (5a), save its residuals $(\mu)$ and carry out an auxiliary regression like the following one.

$$
\mu=\beta_{0}+\beta_{1} H R P G P+\beta_{2} H R P 2 G P+\beta_{3} H R P P_{3 G P}+e
$$

Then the test statistic $\left(n R^{2}\right)$ is computed, which asymptotically (in large sample cases) follows $\chi^{2}$ distribution, meaning that, if the value of $n R^{2}$ does not exceed critical value of $\chi^{2}$, the original estimated model is not under-fitted, and if exceeds, the model is misspecified. Running model $5 \mathrm{~b}$ yields the results that were reported in appendix XI. First, the newly run auxiliary regression analysis is highly insignificant in terms of almost all types of diagnostic statistics. Second, the LM test statistic estimates at:

$$
n R^{2}=100(0.009)=0.9
$$

which does not exceed $\chi^{2}=5.9914$ at $p=0.05$ and DF $=2$; hence or original estimated model $4 \mathrm{c}$ is not misspecified.

\section{J. Interpretation of results}

Reproducing estimated model $4(\mathrm{a}-\mathrm{c})$ :

$$
\begin{aligned}
& \operatorname{FPR}(E D)=\alpha_{0}+\alpha_{1} E D+e=0.164+0.009 E D \\
& \text { (0.110) (0.119) } \\
& R^{2}=0.025 R^{2} \text { adjusted }=0.015 \quad F=2.468(p=0.119) \\
& \mathrm{DW}=1.362 \\
& \operatorname{HRP}(G P)=\gamma_{0}+\gamma_{1} G P+\mu=2.348+0.290 G P \\
& \text { (0.000) (0.000) } \\
& \mathrm{R} 2=0.196 \quad \mathrm{R}_{\text {adjusted }}^{2}=0.188 \quad \mathrm{~F}=23.944(\mathrm{p}=0.000) \\
& \mathrm{DW}=1.724 \\
& \mathrm{FPR}_{\mathrm{ED}, \mathrm{HRP}(\mathrm{GP})}=\beta_{0}+\beta_{1} \mathrm{HRPGP}+_{\varepsilon}=0.241+.024 \mathrm{HRP} \mathrm{GP}_{\mathrm{GP}} \\
& \text { (0.000) (0.003) } \\
& R^{2}=0.085 \quad R_{\text {adjusted }}^{2}=0.075 \quad F=9.057(p=0.003) \\
& \mathrm{DW}=1.844
\end{aligned}
$$

\section{(Figures in parentheses are p-values)}

The estimated model $6(\mathrm{a}-\mathrm{c})$ is a Structural Equations Model (SEM) consisted of three equations. In the first two equa- tions, educational level of female determines the female job participation, in the first equation, and government policy determines the organizational HR practices and policies, in the second equation.

The third equation depends upon the estimations of the first two equations; the predicted values of organizational HR practices and policies are found to be further affecting the predicted values of female participation rates.

\section{CONCLUSIONS AND RECOMMENDATIONS}

The findings of this research help us make certain conclusions, namely:

First, on the basis of the survey involving respondents of this study, it can be inferred that the female employmentparticipation rate (FPR) is 0.3228 , suggesting that a little less than one-third of female are employed. 'Economic-need' is the major reason for female participation in jobs, followed by empowerment and independence. Majority of respondents, $65 \%$ faced 'difficulty in finding jobs' while $73 \%$ found 'not enough job opportunities' according to their skills.

Second, the respondents' perception regarding government policy on female job participation is positive; their average responses on 'whether government is supportive' and 'whether government has certain encouraging laws' have been 3.60 and 3.56, indicating that majority of respondents adopted positions in-between the 'Neutral' and 'Agreed' categories.

Third, the respondents mostly appear positive regarding organizational HR practices and policies. However, they still feel the need that their jobs be made more secured, and their work be valued, as well.

Fourth, the econometrically estimated models suggest that the female educational levels determine the female job participation, and government policy determines the organizational HR practices and policies, and the so determined organizational $\mathrm{HR}$ practices and policies then in turn determine the female participation. This model provides a basis for carrying out larger studies, aiming at bridging the existing gap in literature, on the public and private sectors roles in female job participation.

Though the respondents' perceptions regarding organizational HR practices and policies seem positive, they still feel the need of making their jobs secured, and their participation valuable. Public and private sector policy makers should take note of this situation, and take appropriate needed actions. Government policies have been found positively affecting and determining private sector organizational HR practices and policies. For a more effective private sector female participa- 
tion, the government policies need to be further strengthened and substantiated. The model developed and tested in this research provides a good basis for carrying out further research, aiming at bridging the existing gap in literature on female job participation on the role of the public and private sectors organizations in Pakistan; there is a need as well as great scope of replication of this model across private sector organizations.

\section{APPENDIX I}

APPENDIX I (QUESTIONNAIRE) IS PROVIDED AT THE END

APPENDIX II DESCRIPTIVE STATISTICS

\begin{tabular}{|l|l|l|l|l|l|}
\hline & $\mathrm{N}$ & Min & Max & Mean & S. D. \\
\hline Age in years & 100 & 22.00 & 35.00 & 28.6800 & 3.66771 \\
\hline $\begin{array}{l}\text { Education } \\
\text { in years }\end{array}$ & 100 & 16.00 & 22.00 & 17.7400 & 1.83468 \\
\hline $\begin{array}{l}\text { Experience } \\
\text { in years }\end{array}$ & 100 & 1.00 & 8.00 & 4.0900 & 2.05035 \\
\hline
\end{tabular}

APPENDIX III

DATA ON FEMALE PARTICIPATION RATE

\begin{tabular}{|l|l|l|l|l|l|}
\hline Particulars & N & Min & Max & Mean & S.D. \\
\hline $\begin{array}{l}\text { Female em- } \\
\text { ployed in family }\end{array}$ & 100 & 1.00 & 3.00 & 1.4200 & .60603 \\
\hline $\begin{array}{l}\text { Total female } \\
\text { family members }\end{array}$ & 100 & 1.00 & 9.00 & 3.5000 & 1.64838 \\
\hline $\begin{array}{l}\text { Female-relatives } \\
\text { employed }\end{array}$ & 100 & .00 & 7.00 & 2.5100 & 1.45987 \\
\hline $\begin{array}{l}\text { Total female } \\
\text { relatives }\end{array}$ & 100 & 3.00 & 20.00 & 8.1000 & 3.21769 \\
\hline $\begin{array}{l}\text { Female-neigh- } \\
\text { bours employed }\end{array}$ & 100 & .00 & 7.00 & 2.6500 & 1.67196 \\
\hline $\begin{array}{l}\text { Total female } \\
\text { neighbours }\end{array}$ & 100 & 2.00 & 19.00 & 8.8100 & 3.59768 \\
\hline $\begin{array}{l}\text { Total females } \\
\text { employed (TFE) }\end{array}$ & 100 & 2.00 & 15.00 & 6.5800 & 2.80757 \\
\hline $\begin{array}{l}\text { Total females } \\
\text { surveyed (TFS) } \\
\text { ticipation rate } \\
\text { TFS) }\end{array}$ & 100 & 9.00 & 37.00 & 20.4100 & 5.89315 \\
\hline $\begin{array}{l}\text { Female par- } \\
\text { fouted (TFE/ }\end{array}$ & 0.13 & 0.64 & .3228 & .10478 \\
\hline
\end{tabular}

APPENDIX IV

A. NUMBER OF REASONS DOING JOBS

\begin{tabular}{|l|c|c|c|c|c|}
\hline & $\mathrm{N}$ & Min & Max & Mean & S.D. \\
\hline $\begin{array}{l}\text { Number of rea- } \\
\text { sons doing jobs }\end{array}$ & 100 & 1.00 & 4.00 & 1.58 & .65412 \\
\hline
\end{tabular}

B. RESPONDENTS-ANSWERED 'YES'

\begin{tabular}{|l|l|l|l|}
\hline Empowerment & Independence & $\begin{array}{c}\text { Economic } \\
\text { needs }\end{array}$ & $\begin{array}{c}\text { Feel-not- } \\
\text { bored }\end{array}$ \\
\hline 44 & 37 & 64 & 13 \\
\hline
\end{tabular}

APPENDIX V JOB OF YOUR CHOICE

\begin{tabular}{|l|l|l|l|l|l|}
\hline & & Frequency & Percent & $\begin{array}{c}\text { Valid } \\
\text { Percent }\end{array}$ & $\begin{array}{c}\text { Cumulative } \\
\text { Percent }\end{array}$ \\
\hline \multirow{3}{*}{ Valid } & No & 28 & 28.0 & 28.0 & 28.0 \\
\cline { 2 - 6 } & Yes & 72 & 72.0 & 72.0 & 100.0 \\
\cline { 2 - 6 } & Total & 100 & 100.0 & 100.0 & \\
\hline
\end{tabular}

APPENDIX VI

A. DIFFICULTIES IN FINDING A JOB

\begin{tabular}{|l|l|l|l|l|l|}
\hline & & Frequency & Percent & $\begin{array}{c}\text { Valid } \\
\text { Percent }\end{array}$ & $\begin{array}{c}\text { Cumulative } \\
\text { Percent }\end{array}$ \\
\hline \multirow{3}{*}{ Valid } & No & 35 & 35.0 & 35.0 & 35.0 \\
\cline { 2 - 6 } & Yes & 65 & 65.0 & 65.0 & 100.0 \\
\cline { 2 - 6 } & Total & 100 & 100.0 & 100.0 & \\
\hline
\end{tabular}

B. NOT ENOUGH JOB OPPORTUNITIES

\begin{tabular}{|l|l|l|l|l|l|}
\hline & & Frequency & Percent & $\begin{array}{c}\text { Valid } \\
\text { Percent }\end{array}$ & $\begin{array}{c}\text { Cumulative } \\
\text { Percent }\end{array}$ \\
\hline \multirow{3}{*}{ Valid } & No & 27 & 27.0 & 27.0 & 27.0 \\
\cline { 2 - 6 } & Yes & 73 & 73.0 & 73.0 & 100.0 \\
\cline { 2 - 6 } & Total & 100 & 100.0 & 100.0 & \\
\hline
\end{tabular}

C. JOB DIFFICULTIES-VARIABE

\begin{tabular}{|l|c|l|c|c|c|}
\hline & $\mathrm{N}$ & \multicolumn{1}{|c|}{ Min } & Max & Mean & S. D. \\
\hline $\begin{array}{l}\text { Job_difficulties_ } \\
\text { variable (DIFJ) }\end{array}$ & 100 & .00 & 1.00 & .6900 & .33919 \\
\hline
\end{tabular}

D. ONE SAMPLE STATISTICS

\begin{tabular}{|l|l|l|l|l|}
\hline & N & Mean & $\begin{array}{l}\text { Std. Devia- } \\
\text { tion }\end{array}$ & $\begin{array}{l}\text { Std. Error } \\
\text { Mean }\end{array}$ \\
\hline $\begin{array}{l}\text { Job_difficulties_- } \\
\text { Variable (DIFJ) }\end{array}$ & 100 & .6900 & .33919 & .03392 \\
\hline
\end{tabular}




\section{E. ONE SAMPLE TEST}

\begin{tabular}{|c|c|c|c|c|c|c|}
\hline \multirow{4}{*}{$\begin{array}{l}\text { Job_ } \\
\text { difficulties } \\
\text { Variable (DIFJ) }\end{array}$} & \multicolumn{6}{|c|}{ Test Value $=0.5$} \\
\hline & \multirow[b]{2}{*}{$\mathrm{t}$} & \multirow[b]{2}{*}{$d f$} & \multirow[b]{2}{*}{ Sig. } & \multirow{2}{*}{$\begin{array}{l}\text { Mean } \\
\text { Differ- } \\
\text { ence }\end{array}$} & \multicolumn{2}{|c|}{$\begin{array}{l}95 \% \text { Confi- } \\
\text { dence Interval } \\
\text { of the Differ- } \\
\text { ence }\end{array}$} \\
\hline & & & & & Lower & Upper \\
\hline & 5.602 & 99 & .000 & 19000 & .1227 & 2573 \\
\hline
\end{tabular}

APPENDIX VII

GOVERNMENT POLICY: DESCRIPTIVE STATISTICS

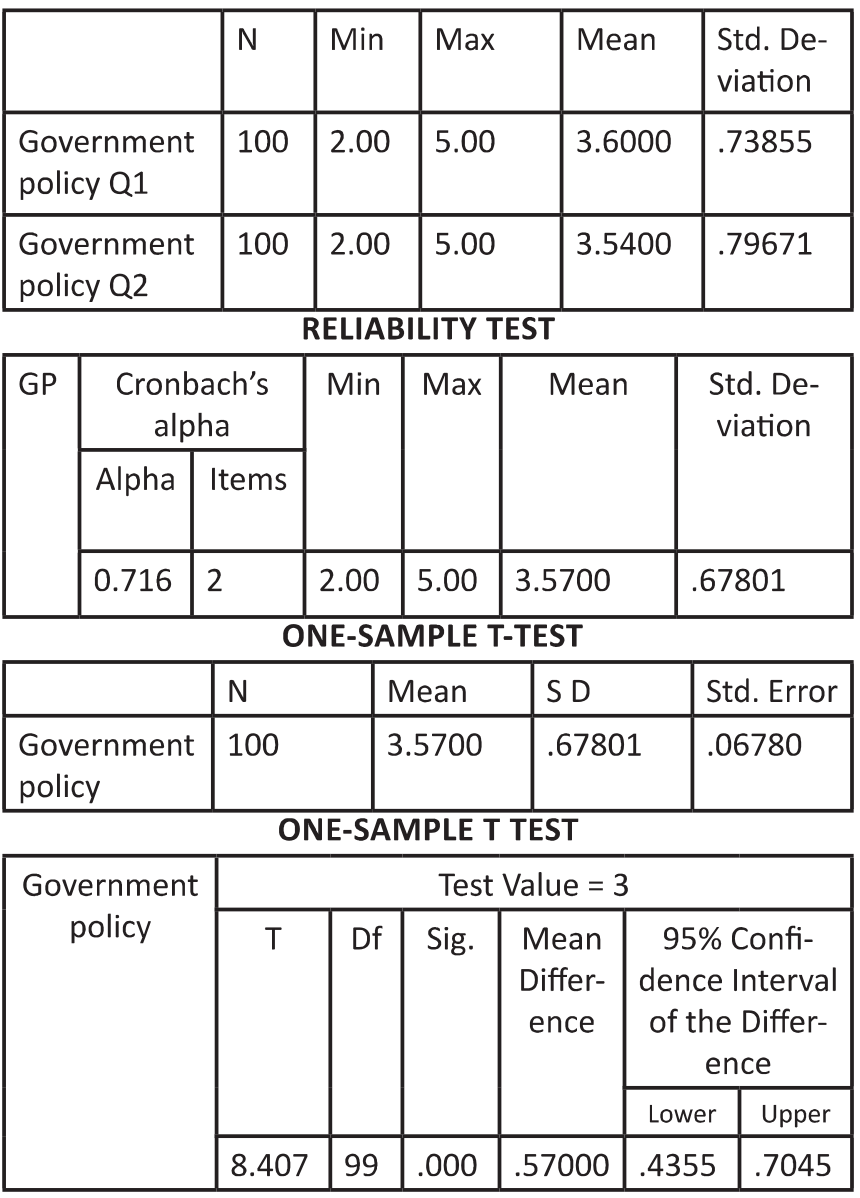

APPENDIX VIII

HR PRACTICES: DESCRIPTIVE STATISTICS

\begin{tabular}{|l|l|l|l|l|l|}
\hline & N & Min & Max & Mean & $\begin{array}{l}\text { Std. De- } \\
\text { viation }\end{array}$ \\
\hline HR practices Q1 & 100 & 2.00 & 5.00 & 3.5500 & .79614 \\
\hline HR practices Q2 & 100 & 2.00 & 5.00 & 3.6900 & .91778 \\
\hline HR practices Q3 & 100 & 2.00 & 5.00 & 3.2100 & .87957 \\
\hline HR practices Q4 & 100 & 1.00 & 5.00 & 2.8200 & 1.04813 \\
\hline
\end{tabular}

\begin{tabular}{|l|l|l|l|l|l|}
\hline HR practices Q5 & 100 & 1.00 & 5.00 & 3.6900 & .86100 \\
\hline HR practices Q6 & 100 & 1.00 & 5.00 & 3.5900 & .75338 \\
\hline HR practices Q7 & 100 & 2.00 & 5.00 & 3.4200 & .71322 \\
\hline HR practices Q8 & 100 & 1.00 & 5.00 & 2.8200 & 1.02868 \\
\hline HR practices Q9 & 100 & 2.00 & 5.00 & 3.4400 & .68638 \\
\hline HR practices Q10 & 100 & 1.00 & 5.00 & 3.5900 & .81767 \\
\hline
\end{tabular}

ONE-SAMPLE T-TEST

\begin{tabular}{|c|c|c|c|c|c|c|}
\hline & \multicolumn{6}{|c|}{ Test Value $=3$} \\
\hline & \multirow[b]{2}{*}{$\mathrm{t}$} & \multirow[b]{2}{*}{ Df } & \multirow[b]{2}{*}{$\begin{array}{c}\text { Sig. } \\
(2 \text {-tailed) }\end{array}$} & \multirow[b]{2}{*}{$\begin{array}{c}\text { Mean } \\
\text { Differ- } \\
\text { ence }\end{array}$} & \multicolumn{2}{|c|}{$\begin{array}{l}95 \% \text { Con- } \\
\text { fidence In- } \\
\text { terval of the } \\
\text { Difference }\end{array}$} \\
\hline & & & & & Lower & Upper \\
\hline HR practices Q1 & 6.908 & 99 & .000 & .55000 & .3920 & .7080 \\
\hline HR practices Q2 & 7.518 & 99 & .000 & .69000 & .5079 & .8721 \\
\hline HR practices Q3 & 2.388 & 99 & .019 & .21000 & .0355 & .3845 \\
\hline HR practices Q4 & -1.717 & 99 & .089 & -.18000 & -.3880 & .0280 \\
\hline HR practices Q5 & 8.014 & 99 & .000 & .69000 & .5192 & .8608 \\
\hline HR practices Q6 & 7.831 & 99 & .000 & .59000 & .4405 & .7395 \\
\hline HR practices Q7 & 5.889 & 99 & .000 & .42000 & .2785 & .5615 \\
\hline HR practices Q8 & -1.750 & 99 & .083 & -.18000 & -.3841 & .0241 \\
\hline HR practices Q9 & 6.410 & 99 & .000 & .44000 & .3038 & .5762 \\
\hline $\begin{array}{l}\text { HR practices } \\
\text { Q10 }\end{array}$ & 7.216 & 99 & .000 & .59000 & .4278 & .7522 \\
\hline
\end{tabular}

HRP VARIABLE: ONE-SAMPLE T-TEST

\begin{tabular}{|l|c|c|c|c|c|}
\hline & $N$ & Min & Max & Mean & $\begin{array}{c}\text { Std. } \\
\text { Deviation }\end{array}$ \\
\hline $\begin{array}{l}\text { HR practices } \\
\text { (HRP) }\end{array}$ & 0.694 & 2.30 & 4.20 & 3.3820 & .44299 \\
\hline
\end{tabular}

ONE-SAMPLE T-TEST

\begin{tabular}{|c|c|c|c|c|c|c|}
\hline & \multicolumn{6}{|c|}{ Test Value $=3$} \\
\hline & \multirow[b]{2}{*}{$\mathrm{T}$} & \multirow[b]{2}{*}{$\mathrm{df}$} & \multirow[b]{2}{*}{ Sig. } & \multirow{2}{*}{$\begin{array}{c}\text { Mean } \\
\text { Difference }\end{array}$} & \multicolumn{2}{|c|}{$\begin{array}{l}95 \% \text { Confi- } \\
\text { dence Interval } \\
\text { of the Differ- } \\
\text { ence }\end{array}$} \\
\hline & & & & & Lower & Upper \\
\hline $\begin{array}{l}\text { HR prac- } \\
\text { tices (HRP) }\end{array}$ & 8.623 & 99 & .000 & .38200 & .2941 & .4699 \\
\hline
\end{tabular}


APPENDIX IX EDUCATION IN YEARS

\begin{tabular}{|l|r|r|r|r|r|}
\hline & $\begin{array}{c}\text { Educational } \\
\text { Level }\end{array}$ & Frequency & $\begin{array}{c}\text { Per- } \\
\text { cent }\end{array}$ & $\begin{array}{c}\text { Valid } \\
\text { Percent }\end{array}$ & $\begin{array}{c}\text { Cumulative } \\
\text { Percent }\end{array}$ \\
\hline Valid & 16.00 & 37 & 37.0 & 37.0 & 37.0 \\
\hline Valid & 18.00 & 51 & 51.0 & 51.0 & 88.0 \\
\cline { 2 - 6 } & 22.00 & 12 & 12.0 & 12.0 & 100.0 \\
\hline
\end{tabular}

\section{APPENDIX $X$}

MODEL 4(A): FPR (ED) $=A_{0}+A_{1} E D+E$

\begin{tabular}{|c|c|c|c|c|c|c|c|c|}
\hline \multicolumn{2}{|c|}{ Model } & $\mathrm{R}$ & R Square & \multicolumn{2}{|c|}{$\begin{array}{l}\text { Adjusted R } \\
\text { Square }\end{array}$} & \multicolumn{2}{|c|}{$\begin{array}{l}\text { Std. Error of } \\
\text { the Estimate }\end{array}$} & $\begin{array}{l}\text { Durbin- } \\
\text { Watson }\end{array}$ \\
\hline \multicolumn{2}{|c|}{1} & $.157 a$ & .025 & .015 & & .104 & & 1.362 \\
\hline \multicolumn{9}{|c|}{ ANNOVA } \\
\hline \multicolumn{3}{|c|}{ Model } & $\begin{array}{l}\text { Sum of } \\
\text { Squares }\end{array}$ & Df & $\begin{array}{l}\mathrm{Me} \\
\mathrm{Squ}\end{array}$ & & $\mathrm{F}$ & Sig. \\
\hline \multirow[t]{3}{*}{1} & \multicolumn{2}{|c|}{ Regression } & .027 & 1 & & 027 & 2.468 & $.119 a$ \\
\hline & \multicolumn{2}{|c|}{ Residual } & 1.060 & 98 & & 011 & & \\
\hline & \multicolumn{2}{|c|}{ Total } & 1.087 & 99 & & & & \\
\hline
\end{tabular}

\section{COEFFICIENTS}

\begin{tabular}{|c|c|c|c|c|c|c|c|c|}
\hline & \multirow[t]{2}{*}{ Model } & \multicolumn{2}{|c|}{$\begin{array}{l}\text { Unstandard- } \\
\text { ized Coef- } \\
\text { ficients }\end{array}$} & \multirow{2}{*}{$\begin{array}{c}\begin{array}{c}\text { Stan- } \\
\text { dardized } \\
\text { Coeffi- } \\
\text { cients }\end{array} \\
\text { Beta }\end{array}$} & \multirow[b]{2}{*}{$\mathrm{t}$} & \multirow[b]{2}{*}{ Sig. } & \multicolumn{2}{|c|}{$\begin{array}{c}\text { Collinearity } \\
\text { Statistics }\end{array}$} \\
\hline & & B & $\begin{array}{l}\text { Std. } \\
\text { Error }\end{array}$ & & & & $\begin{array}{l}\text { Toler- } \\
\text { ance }\end{array}$ & VIF \\
\hline \multirow[t]{2}{*}{1} & (Constant) & .164 & . 102 & & & & & \\
\hline & $\begin{array}{l}\text { Education } \\
\text { in years }\end{array}$ & .009 & .006 & .157 & 1.571 & .119 & 1.000 & 1.000 \\
\hline
\end{tabular}

MODEL 4(B): HRP (GP) $=\Gamma_{0}+\Gamma_{1} G P+M$

\begin{tabular}{|l|l|l|l|l|l|}
\hline Model & $\mathrm{R}$ & $\begin{array}{c}\mathrm{R} \\
\text { Square }\end{array}$ & $\begin{array}{c}\text { Ad- } \\
\text { justed R } \\
\text { Square }\end{array}$ & $\begin{array}{c}\text { Std. Error } \\
\text { of the } \\
\text { Estimate }\end{array}$ & $\begin{array}{l}\text { Durbin- } \\
\text { Watson }\end{array}$ \\
\hline 1 & $.443 a$ & .196 & .188 & .39914 & 1.724 \\
\hline
\end{tabular}

\begin{tabular}{|l|l|l|l|l|l|l|}
\hline \multicolumn{2}{|c|}{ Model } & $\begin{array}{c}\text { Sum of } \\
\text { Squares }\end{array}$ & Df & $\begin{array}{c}\text { Mean } \\
\text { Square }\end{array}$ & $F$ & Sig. \\
\hline \multirow{2}{*}{1} & Regression & 3.815 & 1 & 3.815 & 23.94 & .000 \\
\cline { 2 - 7 } & Residual & 15.613 & 98 & .159 & & \\
\cline { 2 - 7 } & Total & 19.428 & 99 & & & \\
\hline
\end{tabular}

\section{COEFFICIENTS}

\begin{tabular}{|c|c|c|c|c|c|c|c|c|}
\hline & \multirow[t]{2}{*}{ Model } & \multicolumn{2}{|c|}{$\begin{array}{l}\text { Unstan- } \\
\text { dardized } \\
\text { Coeffi- } \\
\text { cients }\end{array}$} & \multirow{2}{*}{$\begin{array}{c}\text { Stan- } \\
\text { dard- } \\
\text { ized } \\
\text { Coeffi- } \\
\text { cients } \\
\text { Beta }\end{array}$} & \multirow[b]{2}{*}{$\mathrm{t}$} & \multirow[b]{2}{*}{ Sig. } & \multicolumn{2}{|c|}{$\begin{array}{l}\text { Collinear- } \\
\text { ity Statis- } \\
\text { tics }\end{array}$} \\
\hline & & B & $\begin{array}{l}\text { Std. } \\
\text { Error }\end{array}$ & & & & $\begin{array}{l}\text { Toler- } \\
\text { ance }\end{array}$ & VIF \\
\hline \multirow[t]{2}{*}{1} & (Constant) & 2.348 & .215 & & 10.92 & .00 & & \\
\hline & $\begin{array}{l}\text { Education } \\
\text { in years }\end{array}$ & .290 & .059 & .443 & 4.893 & .00 & 1.000 & 1.000 \\
\hline
\end{tabular}
MODEL4(C): FPRED $=\mathrm{B}_{0}+\mathrm{B}_{1}$ HRPGP $+\mathrm{E}$

\begin{tabular}{|l|c|r|r|r|r|}
\hline Model & $\mathrm{R}$ & $\mathrm{R}$ \\
Square & $\begin{array}{c}\text { Adjusted } \mathrm{R} \\
\text { Square }\end{array}$ & $\begin{array}{c}\text { Std. Error of } \\
\text { the } \\
\text { Estimate }\end{array}$ & $\begin{array}{c}\text { Durbin- } \\
\text { Watson }\end{array}$ \\
\hline 1 & $.291 \mathrm{a}$ & .085 & .075 & .01579179 & 1.844 \\
\hline
\end{tabular}

\begin{tabular}{|l|l|r|r|r|r|c|}
\hline \multicolumn{2}{|l|}{ Model } & $\begin{array}{r}\text { Sum of } \\
\text { Squares }\end{array}$ & Df & $\begin{array}{c}\text { Mean } \\
\text { Square }\end{array}$ & F & Sig. \\
\hline \multirow{2}{*}{1} & Regression & .002 & 1 & .002 & 9.057 & $.003 a$ \\
\cline { 2 - 7 } & Residual & .024 & 98 & .000 & & \\
\cline { 2 - 7 } & Total & .027 & 99 & & & \\
\hline
\end{tabular}

\section{COEFFICIENTS}

\begin{tabular}{|c|c|c|c|c|c|c|c|c|}
\hline & \multirow[t]{2}{*}{ Model } & \multicolumn{2}{|c|}{$\begin{array}{l}\text { Unstan- } \\
\text { dardized } \\
\text { Coeffi- } \\
\text { cients }\end{array}$} & \multirow{2}{*}{$\begin{array}{c}\text { Stan- } \\
\text { dard- } \\
\text { ized } \\
\text { Coeffi- } \\
\text { cients } \\
\text { Beta }\end{array}$} & \multirow[b]{2}{*}{$t$} & \multirow[b]{2}{*}{ Sig. } & \multicolumn{2}{|c|}{$\begin{array}{c}\text { Collinearity } \\
\text { Statistics }\end{array}$} \\
\hline & & B & $\begin{array}{l}\text { Std. } \\
\text { Error }\end{array}$ & & & & $\begin{array}{l}\text { Toler- } \\
\text { ance }\end{array}$ & VIF \\
\hline \multirow[t]{2}{*}{1} & (Constant) & .241 & .027 & & 8.781 & .00 & & \\
\hline & $\begin{array}{l}\text { Education } \\
\text { in years }\end{array}$ & .024 & .008 & .291 & 3.010 & .003 & 1.000 & 1.000 \\
\hline
\end{tabular}

\section{APPENDIX XI}

MODEL 5: LM TEST

\begin{tabular}{|l|l|l|l|c|l|}
\hline Model & $\mathrm{R}$ & $\begin{array}{c}\mathrm{R} \\
\text { Square }\end{array}$ & $\begin{array}{c}\text { Ad- } \\
\text { justed } \mathrm{R} \\
\text { Square }\end{array}$ & $\begin{array}{c}\text { Std. Error } \\
\text { of the } \\
\text { Estimate }\end{array}$ & $\begin{array}{c}\text { Durbin- } \\
\text { Watson }\end{array}$ \\
\hline 1 & $.093 a$ & .009 & -.012 & .01580413 & 1.839 \\
\hline
\end{tabular}

\begin{tabular}{|l|l|r|r|r|r|c|}
\hline \multicolumn{2}{|l|}{ Model } & $\begin{array}{r}\text { Sum of } \\
\text { Squares }\end{array}$ & Df & $\begin{array}{r}\text { Mean } \\
\text { Square }\end{array}$ & F & Sig. \\
\hline \multirow{2}{*}{1} & Regression & .000 & 2 & .000 & .424 & $.656 a$ \\
\cline { 2 - 7 } & Residual & .024 & 97 & .000 & & \\
\cline { 2 - 7 } & Total & .024 & 99 & & & \\
\hline
\end{tabular}




\section{COEFFICIENTS}

\begin{tabular}{|l|l|l|l|l|l|l|}
\hline \multicolumn{2}{|c|}{ Model } & \multicolumn{2}{|l|}{$\begin{array}{l}\text { Unstandardized } \\
\text { Coefficients }\end{array}$} & $\begin{array}{l}\text { Standardized } \\
\text { Coefficients }\end{array}$ & & \\
\cline { 2 - 5 } & B & $\begin{array}{l}\text { Std. } \\
\text { Error }\end{array}$ & Beta & \multirow{2}{*}{ Sig. } \\
\hline \multirow{2}{*}{1} & (Constant) & .215 & .235 & & & \\
\cline { 2 - 5 } & HRP & -.098 & .107 & -1.22 & -.918 & .361 \\
\hline & HRP3 & .003 & .003 & 1.226 & .920 & .360 \\
\hline
\end{tabular}

\section{REFERENCES}

[1] Ejaz, M. (2007). Determinants of Female Labor Force Participation in Pakistan: An Empirical Analysis of PSLM (2004-05) Micro Data. The Lahore Journal of Economics Special Edition.

[2] Engle, R.F. (1982). A General Approach to Lagrangian Multiplier Model Diagnostics. Journal of Econometrics. 20, 83-104
[3] Fatima,A. and Sultana, H. (2009). Tracing out the Ushape relationship between female labor force participation rate and economic development for Pakistan, International Journal of Social Economics, 36, 182 198.

[4] Gujarati, D.N. (2007). Applied Econometrics, 4th Edition, pp. 534-535.

[5] Hafeez, A. and Ahmad, E. (2002). Factors determining the labour force participation decision of educated married women in a district of Punjab. Pakistan Economic and Social Review, 1, 75-88.

[6] Hausmann, R., Tyson, L.D. and Zahidi, S. (2011). The Global Gender Gap Report 2011, World Economic Forum, Geneva, Switzerland.

[7] ILO (2009). Global Employment Trends for Women March 2009. International Labour Office. - Geneva.

[8] Naqvi, Z.F. and Shahnaz, L.. How do women decide to work in Pakistan? Available on: http://www.pide.org. pk/pdf/psde/18AGM.pdf

[9] U.S. Department of Labor (2012). Working in the 21st Century: Labor Force Participation Rates, 1975 -2008.

\section{BIOGRAPHIES}

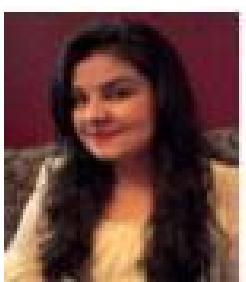

Muniba Sana has worked with Transworld Associates as a Marketing Executive. She has obtained a Master's degree in Management from the University of Leicester, UK. She did her Bachelor's degree in Business Administration from Bahria University, Islamabad. Her areas of interest are labor studies and empowerment of women. 